\title{
cmaJOPEN
}

\section{Health expenditures after first hospital admission for heart failure in Nova Scotia, Canada: a retrospective cohort study}

\author{
Adrian R. Levy PhD, Karissa M. Johnston PhD, Alexia Daoust MSc, Andrew Ignaszewski MD, \\ Jonathan Fortier MSc, Basia Rogula MSc, Paul Oh MD
}

\section{Abstract}

Background: Although the frequency of heart failure makes it among the costliest of illnesses, there are scant Canadian data on annual costs of treatment or the costs as the condition advances. Our objective was to estimate mean prevalence- and incidencebased direct medical costs among older adults discharged alive after a first hospital admission for heart failure.

Methods: We conducted a retrospective cohort study using population-based administrative health databases for Nova Scotia. The cohort comprised persons 50 years of age or older with an incident hospital admission for heart failure between 2009 and 2012. We considered the costs (expressed as 2020 Canadian dollars) of hospital admissions, physician visits and, for patients 65 years of age or older, outpatient cardiac medications. We estimated costs for calendar years, longitudinally and in the last 2 years of life. We analyzed costs from the perspective of a third-party public payer.

Results: The cohort consisted of 3327 patients (mean age 77.6 yr; 1605 [48.2\%] women). Median survival was 2.5 and 2.2 years among men and women, respectively. Annual prevalence-based costs were about $\$ 7100$. Mean incidence-based costs ranged between $\$ 65000$ and $\$ 164000$ in the year after diagnosis and decreased by $90 \%$ subsequently. Costs were 4 to 7 times higher in the year before death than in the period from 1 to 2 years before death.

Interpretation: The direct medical costs of treating patients with heart failure in Nova Scotia displayed a reverse $\mathrm{J}$ shape, with costs highest after diagnosis, declining subsequently and then increasing during the final year of life. Strategies designed to improve the quality of care immediately after diagnosis and during more advanced stages of disease might reduce these costs.

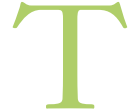
reating people with heart failure imposes enormous economic burdens on all developed countries, accounting for between $1 \%$ and $2 \%,{ }^{1,2}$ and possibly as high as $3.2 \%,{ }^{3}$ of total annual direct medical costs. These costs arise because heart failure is common, its incidence increases rapidly after middle age, and its management requires high-intensity care, including regular hospital admissions. According to the Canadian Institute for Health Information (CIHI), heart failure is the third most common reason for hospital admission in Canada, ${ }^{4}$ has the highest rates of readmission ${ }^{5}$ and is the second most costly cause of admission. ${ }^{6}$ As such, it is considered an important driver of health care resource utilization in Canadian health care systems. ${ }^{7,8}$

Despite these figures, there exists scant reliable information on resource use and costs on which to base strategies and policies for managing the care of Canadians with a diagnosis of heart failure. For example, a systematic review of cost-ofillness studies published between 2004 and 2016 yielded no Canadian studies on the topic, ${ }^{9}$ and another on studies published between 2003 and $2015^{10}$ yielded only 1 Canadian study, which examined costs in the first year after discharge. ${ }^{11}$
Studies from other jurisdictions can provide benchmarks and knowledge applicable to Canada, although mean annual costs vary substantially by jurisdiction. ${ }^{12,13}$ Investigators have shown that the largest component of direct medical costs more than $50 \%$ - relates to hospital admission, followed by medications; ${ }^{9}$ that newly diagnosed patients have higher costs than those later in the course of disease; and that direct medical costs increase during the final months of life. ${ }^{14-16}$

Competing interests: Adrian Levy has served as a paid consultant to Broadstreet Health Economics \& Outcomes Research and Novartis Pharmaceuticals Canada Inc. Karissa Johnston and Basia Rogula have served as paid consultants to Novartis Pharmaceuticals Canada Inc. Alexia Daoust and Jonathan Fortier are employees and shareholders of Novartis Pharmaceuticals Canada Inc. Paul Oh has participated on advisory boards funded by Amgen, Astra Zeneca and Novartis. No other competing interests were declared.

This article has been peer reviewed.

Correspondence to: Adrian Levy, adrian.levy@dal.ca

CMAJ Open 2021 August 26. DOI:10.9778/cmajo.20200230 
Reliable estimates of the direct medical costs of heart failure are required for important evaluative and research purposes. The costs of illness can be useful for various reasons: identifying differences in the distribution of costs among demographic groups or jurisdictions, which can be used to generate hypotheses about reducing costs; highlighting areas where practice variations occur; and identifying potentially inefficient uses of resources. These hypotheses can, in turn, help determine research and funding priorities. ${ }^{17,18}$ Costof-illness studies are also needed to quantify changes that may arise through new management approaches or public policies. ${ }^{17}$ From a public health perspective, the distribution of costs can be used to identify potential areas of inequitable allocation of resources. ${ }^{18}$ It can also provide reliable inputs for cost-effectiveness models, which otherwise may be based on costs collected during randomized trials (which may not reflect actual practice).

Two approaches to the costing of illness exist: incidencebased and prevalence-based. The incidence-based approach involves calculating the costs of treatment for typical individuals from diagnosis until death (or resolution), whereas the prevalence-based approach estimates the total cost to a population living with the disease incurred in a given calendar year. ${ }^{17}$ To our knowledge, there are no published Canadian estimates using either approach for heart failure. Our objective was to estimate, among residents of Nova Scotia, Canada, aged 50 years or older who were discharged alive after a first hospital admission for heart failure, the mean overall prevalence-based (2013-2015) and incidence-based (20092015) direct medical costs. We also report direct medical costs in the 2 years before death.

\section{Methods}

\section{Study design and participants}

We conducted a retrospective, population-based cohort study using Nova Scotia administrative health databases for hospital discharge abstracts, physician billing claims, prescription claims for persons aged 65 years or older, and death certificates. These data, which were linked using encrypted identifiers, ${ }^{19}$ included records for medical and hospital services for all provincial health plan registrants in Nova Scotia (more than $98 \%$ of the province's 923598 residents, of whom 183820 were $65 \mathrm{yr}$ of age or older) in 2016.

The study population consisted of all registered Nova Scotians aged 50 years or older who had a "most responsible diagnosis" code of heart failure (International Statistical Classification of Diseases and Related Health Problems [ICD], 10th Revision code 150.x) between 2009 and 2012, after removal of anyone with a hospital discharge abstract that included any heart failure coded in 2007 or 2008.

Although there has been little assessment of the reliability of coding of these databases in Nova Scotia, ${ }^{20}$ studies in other Canadian provinces have indicated that the algorithm we used generally yields higher specificity and lower sensitivity, indicating high confidence that the individuals in the sample were likely to have suffered acute decompensated heart failure ${ }^{21}$ while excluding some suitable patients. ${ }^{22,23}$ There is no a priori reason to think that patients whose heart failure was coded with a different discharge diagnosis were systematically different from those included in the analysis.

Given that a diagnosis of heart failure in patients younger than 50 years is rare and often of nonischemic origin (and thus may have different resource implications ${ }^{24}$ ), we included only individuals 50 years of age or older at the time of the first hospital episode for heart failure. We calculated incidence rates per 100000 using age- and sex-specific population denominators. ${ }^{25}$ We calculated duration of survival using the date of the index admission and the date of death on the death certificate. We illustrated all-cause mortality using Kaplan-Meier curves.

\section{Resource use and costs}

We performed the costing analysis from the perspective of a third-party public payer (i.e., the Nova Scotia Department of Health and Wellness) using a bottom-up ("person-based"), rather than a top-down ("population-based"), approach. ${ }^{26}$ Medical resources included hospital admissions, physician visits and, for persons aged 65 years or older, cardiac medications. We stratified the costs by sex and age (50 to $<65,65-80$ and $>80 \mathrm{yr}$ ) on the admission date for the index admission. We attributed costs to the year of follow-up after hospital discharge, with patients censored on the date of death, end of enrolment or Mar. 31, 2016.

To facilitate future disaggregated comparisons with other jurisdictions, we did not use resource-intensity weights ${ }^{27}$ but instead estimated mean annual costs of a hospital stay by multiplying the mean length of stay by a per-diem cost. We tabulated the per-diem costs of hospital stays separately for medical wards and intensive care or coronary care units on the basis of Canadian means from CIHI, ${ }^{28}$ inflated to 2020 using the consumer price index, ${ }^{29}$ which yielded values of $\$ 1139$ for a day on a general ward and $\$ 3976$ for a day in the intensive care unit. We attributed hospital costs to the year in which the admission date fell. We obtained physician fees for all visits to family physicians, cardiologists and cardiac surgeons from the Nova Scotia physician fee schedule. ${ }^{30}$

We included the costs of outpatient medications only for those older than 65 years because this is the age at which the costs are reimbursed by Nova Scotia Pharmacare, and this is therefore the group for whom electronic dispensation claims were available. Medications administered in hospital were included in hospital budgets and could not be isolated. We based the costs of cardiovascular medications on the World Health Organization's Anatomical Therapeutic Chemical classification system for drugs, adapted from the Nova Scotia Pharmacare Drug Formulary ${ }^{31}$ (Appendix 1, available at www. cmajopen.ca/content/9/3/E826/supp1/DC1). We multiplied daily medication costs by the number of days supplied to obtain the cost of the dispensation; we excluded dispensing fees.

\section{Statistical analysis}

Following conventional principles of cost-of-illness analysis, ${ }^{32}$ we estimated both incidence- and prevalence-based costs of heart failure in Nova Scotia. These analyses differ from 
cost-effectiveness studies in that they do not include an intervention, comparator groups or clinical outcomes.

For incidence-based costs, we began with the initial admission for heart failure and longitudinally tabulated costs for up to 7 years (2009 to 2015) after diagnosis. For this analysis, we excluded patients with a hospital admission for heart failure in 2007 or 2008.

For prevalence-based costs, we began tabulation with the initial admission for heart failure (including patients who died) and calculated the annual mean for the 3 most recent years available (2013 to 2015). We tabulated the costs in the first and second years before death, accounting for leftcensoring for those who survived less than 2 years. For example, those who died on day 365 of follow-up contributed data only to the first year and last year of life categories. Rather than medians, we report mean (and standard deviation [SD]) values because they provide more accurate estimates of total budgets and are thus more useful for policy-making. ${ }^{32,33} \mathrm{We}$ report all costs in 2020 Canadian dollars.

\section{Ethics approval}

This study was approved by the Dalhousie University Health Sciences Research Ethics Board (2016-3979).

\section{Results}

A total of 3327 persons aged 50 years and older were discharged from hospital with the most responsible diagnosis code for heart failure between 2009 and 2012. The mean age was 77.6 years, and 1605 (48.2\%) were women. Incidence rates increased by an order of magnitude in each age stratum, were higher among men than women in all 3 age strata, and declined in both sexes and all age strata over the period 2009 to 2012 (Table 1).

All-cause mortality after a diagnosis of heart failure was high, with $20 \%$ of individuals dying within 2 months and a median survival of 2.5 years for men and 2.2 years for women after the first hospital discharge for heart failure (Figure 1). Survival over 7 years was slightly higher among men than women. About $20 \%$ of individuals were alive 7 years after the initial diagnosis.

The mean total annual length of stay for entire hospital admissions (general ward plus intensive care unit) was 4.6 days among both men (SD $13.4 \mathrm{~d}$ ) and women (SD $13.8 \mathrm{~d}$ ). The large $\mathrm{SD}$ relative to the mean indicates a distribution with a long tail. Among both men and women, the annual length of stay declined with increasing age.

\section{Prevalence-based costs}

Between 2013 and 2015, the mean annual prevalence-based costs for all patients was about $\$ 7100$ for both men and women, assuming the cost of medications is the same in the 50- to 64-year-old group as the older ages (Table 2). The overall cost distribution across resource categories was about $86 \%$ for hospital admissions, $10 \%$ for medications and $4 \%$ for physician services. Mean annual prevalence-based costs declined with age for both men and women. In addition, these costs were higher for women than for men in each age stratum; however, because of different distributions of age, the weighted means of both sexes were similar. Among men, the dispersion (SDs) of annual costs were similar across individual age groups and all ages pooled. Among women, the dispersion of annual costs was highest in the youngest group, indicating that some younger women had a greater number of days in hospital and higher costs.

\section{Incidence-based costs}

Mean incidence-based costs were highest in the first year after hospital admission for heart failure, ranging from about $\$ 65000$ for men aged 50 to 64 years to $\$ 164000$ for men older than 80 years and from about $\$ 93000$ for women aged 50 to 64 years to almost $\$ 144000$ for women older than 80 years (Table 3 ). For those who survived until the second year after discharge, incidence-based costs decreased by about $83 \%$ in the second year and continued to decline more slowly over time, such that by 7 years after the initial admission for heart failure, costs (over all age groups) were 92\% lower than in the first year. Given the median survival of 2.2 years for women and 2.5 years for men (Figure 1), the relatively few patients surviving beyond 3 years showed increased dispersion (i.e., SD) of the mean costs.

\section{Direct medical costs}

Compared with the period from 1 to 2 years before death, direct medical costs were between 4 and 7 times higher in the

Table 1: Rates of first hospital discharge for heart failure* among Nova Scotia residents 50 years or older, 2009 to 2012

\begin{tabular}{|c|c|c|c|c|c|c|c|c|c|}
\hline \multirow[b]{3}{*}{ Year } & \multicolumn{9}{|c|}{ Sex; age group, yr; rate per 100000 (count, $n$ ) } \\
\hline & \multicolumn{4}{|c|}{ Men } & \multicolumn{4}{|c|}{ Women } & \multirow[b]{2}{*}{ All patients } \\
\hline & $50-64$ & $65-80$ & $>80$ & All men $\geq 50$ & $50-64$ & $65-80$ & $>80$ & All women $\geq 50$ & \\
\hline 2009 & $83(84)$ & $414(216)$ & $1505(178)$ & $289(478)$ & $44(46)$ & $292(173)$ & $925(213)$ & $230(432)$ & $258(910)$ \\
\hline 2010 & $91(94)$ & $368(198)$ & $1159(141)$ & $256(433)$ & $39(42)$ & $221(134)$ & $987(229)$ & $211(405)$ & $232(838)$ \\
\hline 2011 & $81(85)$ & $322(180)$ & $1307(161)$ & $246(426)$ & $35(39)$ & $226(141)$ & $991(231)$ & $210(411)$ & $227(837)$ \\
\hline 2012 & $67(71)$ & 294 (173) & 1109 (141) & 217 (385) & 30 (33) & 213 (139) & 779 (185) & $178(357)$ & $196(742)$ \\
\hline
\end{tabular}




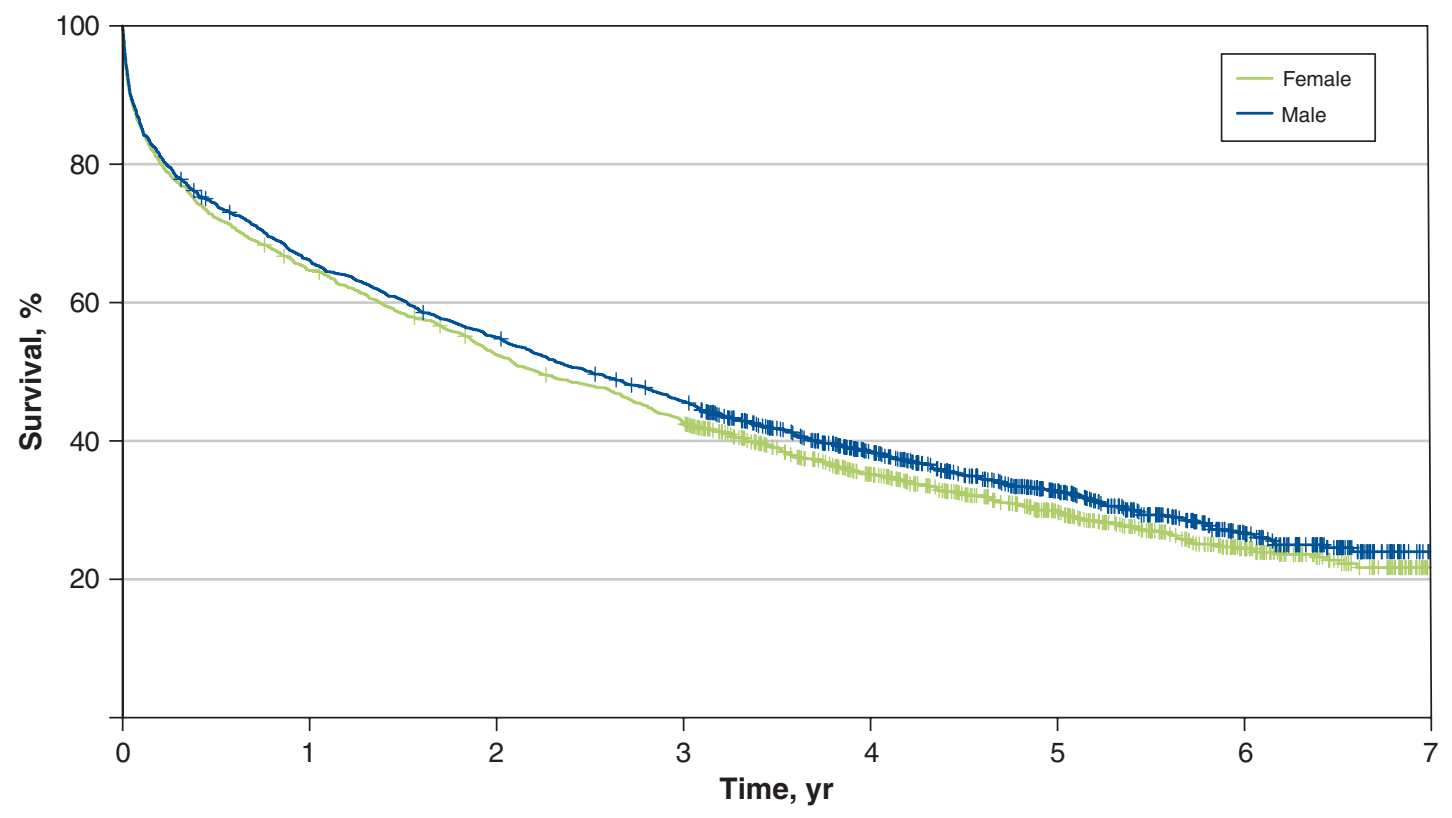

Figure 1: Kaplan-Meier curve for death from any cause after first hospital admission for heart failure among Nova Scotia residents aged 50 years or older, by sex, 2009 to 2012.

year before death (Table 4). The costs in the year before death were still substantially lower than in the first year after diagnosis (Table 3 ).

\section{Interpretation}

For patients admitted to hospital for heart failure in Nova Scotia, costs were highest in the first year after admission, then decreased to a relatively stable lower level and increased again toward the end of life. The initial pattern is similar to curves reported from other jurisdictions, ${ }^{34}$ and the increased costs in the last year of life are consistent with a previous Canadian study. ${ }^{16}$ Selection of patients according to the most responsible diagnosis led to an estimate of mean annual prevalence-based costs in Nova Scotia of about $\$ 7100$. Hospital admissions formed the biggest cost driver, being about 6 times greater than the costs of medication and physician visits combined $(\$ 6055$ v. $\$ 728+\$ 292)$. This approach likely depicts a conservative estimate, termed "heart failure in isolation," ${ }^{3}$ and can appropriately represent the lower bound of the costs of illness. Including the costs of conditions that are comorbid with heart failure, such as hypertension, coronary artery disease, renal insufficiency, diabetes mellitus, chronic obstructive pulmonary disease ${ }^{35}$ or other conditions, ${ }^{2}$ collectively termed "heart failure syndrome," can appropriately represent the upper bound of the costs of illness.

One important audience for this study is Canadian public payers (i.e., hospitals and ministries of health), provided the results are applicable to their jurisdictions. The mean length of stay that we have reported for Nova Scotia (4.6 [SD 13.6] d) was lower than that reported from other Canadian provinces $^{36}$ and in the US Medicare hospitalization files (mean 4.9 [SD 3.5] d).$^{37}$ Some of this difference may be due to differences in study designs. Those previous authors calculated the mean cost of individual hospital episodes; in contrast, for our prevalence-based estimates from Nova Scotia, we calculated the mean annual total number of hospital days between 2013 and 2015. As such, the methods employed here reflect the perspective of Canadian public payers, not that of patients. These results from Nova Scotia may be generalizable to publicly funded health care systems that are not centrally organized.

Mean prevalence-based costs declined with advancing age among both men and women, with the youngest age group being the costliest (even without including outpatient medications; Table 2). In contrast, mean incidence-based costs showed the opposite pattern, with increasing costs for older groups in most years of follow-up (Table 3). This finding arises from the different designs and interpretations of the analyses: prevalence-based cost-of-illness studies include a cross-section of individuals and therefore reflect an amalgam of costs at various stages of heart failure, ${ }^{38}$ whereas incidencebased designs show how costs vary in each age group.

Comparing the mean annual cost of about $\$ 7100$ with estimates from other countries is fraught with conceptual and methodologic challenges, ${ }^{9}$ including the selection of patients (focus on heart failure in isolation v. heart failure syndrome), 


\begin{tabular}{|c|c|c|c|c|c|c|c|c|c|c|c|}
\hline \multirow[b]{3}{*}{ Age group, yr } & \multicolumn{11}{|c|}{ Category of expenditure; length of stay or cost, mean \pm SD } \\
\hline & \multicolumn{2}{|c|}{ General ward } & \multicolumn{2}{|c|}{ ICU } & \multicolumn{2}{|c|}{ General ward + ICU } & \multicolumn{2}{|c|}{ Physician visits* } & \multicolumn{2}{|c|}{$\begin{array}{c}\text { Outpatient cardiovascular } \\
\text { medications } \dagger\end{array}$} & \multirow[b]{2}{*}{$\begin{array}{c}\text { Total } \\
\text { cost,§ \$ }\end{array}$} \\
\hline & $\begin{array}{l}\text { Length of } \\
\text { stay, d }\end{array}$ & Cost, $\ddagger \$$ & $\begin{array}{l}\text { Length of } \\
\text { stay, } d\end{array}$ & Cost, $\neq \$$ & $\begin{array}{l}\text { Length of } \\
\text { stay, d }\end{array}$ & Cost, $\ddagger \$$ & $\begin{array}{l}\text { No. of } \\
\text { visits }\end{array}$ & Cost, $\$$ & $\begin{array}{c}\text { No. of } \\
\text { dispensations }\end{array}$ & Cost, $\$$ & \\
\hline \multicolumn{12}{|l|}{ Men } \\
\hline $50-64$ & $\begin{array}{c}4.9 \pm \\
12.1\end{array}$ & $\begin{array}{l}5534 \pm \\
13773\end{array}$ & $\begin{array}{c}0.6 \pm \\
2.0\end{array}$ & $\begin{array}{l}2221 \pm \\
7875\end{array}$ & $\begin{array}{c}5.4 \pm \\
12.8\end{array}$ & $\begin{array}{l}7754 \pm \\
17635\end{array}$ & $\begin{array}{l}17.1 \pm \\
24.3\end{array}$ & $\begin{array}{c}447 \pm \\
792\end{array}$ & NA & NA & $\begin{array}{l}8201 \pm \\
17978\end{array}$ \\
\hline $65-80$ & $\begin{array}{l}5.0 \pm \\
13.7\end{array}$ & $\begin{array}{l}5663 \pm \\
15615\end{array}$ & $\begin{array}{c}0.3 \pm \\
1.4\end{array}$ & $\begin{array}{c}1245 \pm \\
5444\end{array}$ & $\begin{array}{l}5.3 \pm \\
14.0\end{array}$ & $\begin{array}{l}6908 \pm \\
17430\end{array}$ & $\begin{array}{c}14.1 \pm \\
26.0\end{array}$ & $\begin{array}{c}365 \pm \\
808\end{array}$ & $\begin{array}{c}26.4 \pm \\
43.4\end{array}$ & $\begin{array}{c}856 \pm \\
1009\end{array}$ & $\begin{array}{l}8129 \pm \\
17906\end{array}$ \\
\hline$>80$ & $\begin{array}{l}3.2 \pm \\
12.8\end{array}$ & $\begin{array}{l}3610 \pm \\
14536\end{array}$ & $\begin{array}{l}0.1 \pm \\
0.9\end{array}$ & $\begin{array}{l}494 \pm \\
3701\end{array}$ & $\begin{array}{c}3.3 \pm \\
13.0\end{array}$ & $\begin{array}{l}4104 \pm \\
15776\end{array}$ & $\begin{array}{l}8.7 \pm \\
19.7\end{array}$ & $\begin{array}{c}193 \pm \\
521\end{array}$ & $\begin{array}{l}13.3 \pm \\
33.6\end{array}$ & $\begin{array}{c}422 \pm \\
807\end{array}$ & $\begin{array}{l}4719 \pm \\
16172\end{array}$ \\
\hline All men $\geq 50$ & $\begin{array}{l}4.3 \pm \\
13.1\end{array}$ & $\begin{array}{l}4897 \pm \\
14909\end{array}$ & $\begin{array}{c}0.3 \pm \\
1.4\end{array}$ & $\begin{array}{l}1163 \pm \\
5523\end{array}$ & $\begin{array}{l}4.6 \pm \\
13.4\end{array}$ & $\begin{array}{l}6061 \pm \\
16950\end{array}$ & $\begin{array}{l}12.7 \pm \\
23.8\end{array}$ & $\begin{array}{c}319 \pm \\
721\end{array}$ & $\begin{array}{c}20.5 \pm \\
39.8\end{array}$ & $\begin{array}{c}662 \pm \\
949\end{array}$ & $\begin{array}{l}6380 \pm \\
17346\end{array}$ \\
\hline \multicolumn{12}{|l|}{ Women } \\
\hline $50-64$ & $\begin{array}{c}6.0 \pm \\
14.6\end{array}$ & $\begin{array}{l}6820 \pm \\
16575\end{array}$ & $\begin{array}{l}1.0 \pm \\
8.0\end{array}$ & $\begin{array}{l}3995 \pm \\
31960\end{array}$ & $\begin{array}{c}7.0 \pm \\
17.3\end{array}$ & $\begin{array}{c}10815 \pm \\
37383\end{array}$ & $\begin{array}{c}16.5 \pm \\
25.7\end{array}$ & $\begin{array}{c}416 \pm \\
812\end{array}$ & NA & NA & $\begin{array}{c}11231 \pm \\
37871\end{array}$ \\
\hline $65-80$ & $\begin{array}{l}5.7 \pm \\
14.8\end{array}$ & $\begin{array}{l}6457 \pm \\
16823\end{array}$ & $\begin{array}{c}0.2 \pm \\
1.1\end{array}$ & $\begin{array}{l}953 \pm \\
4324\end{array}$ & $\begin{array}{l}5.9 \pm \\
15.1\end{array}$ & $\begin{array}{l}7410 \pm \\
18317\end{array}$ & $\begin{array}{c}14.8 \pm \\
23.2\end{array}$ & $\begin{array}{c}347 \pm \\
679\end{array}$ & $\begin{array}{c}34.4 \pm \\
52.7\end{array}$ & $\begin{array}{c}956 \pm \\
1353\end{array}$ & $\begin{array}{l}8712 \pm \\
18815\end{array}$ \\
\hline$>80$ & $\begin{array}{l}3.1 \pm \\
11.1\end{array}$ & $\begin{array}{l}3501 \pm \\
12627\end{array}$ & $\begin{array}{l}0.2 \pm \\
2.0\end{array}$ & $\begin{array}{l}728 \pm \\
7993\end{array}$ & $\begin{array}{c}3.3 \pm \\
11.9\end{array}$ & $\begin{array}{l}4228 \pm \\
17135\end{array}$ & $\begin{array}{c}8.2 \pm \\
18.8\end{array}$ & $\begin{array}{c}175 \pm \\
461\end{array}$ & $\begin{array}{c}20.3 \pm \\
39.3\end{array}$ & $\begin{array}{c}678 \pm \\
767\end{array}$ & $\begin{array}{l}5082 \pm \\
17514\end{array}$ \\
\hline All women $\geq 50$ & $\begin{array}{c}4.3 \pm \\
13.0\end{array}$ & $\begin{array}{l}4913 \pm \\
14769\end{array}$ & $\begin{array}{l}0.3 \pm \\
3.0\end{array}$ & $\begin{array}{l}1136 \pm \\
11964\end{array}$ & $\begin{array}{c}4.6 \pm \\
13.8\end{array}$ & $\begin{array}{l}6048 \pm \\
20559\end{array}$ & $\begin{array}{c}11.4 \pm \\
21.6\end{array}$ & $\begin{array}{c}262 \pm \\
597\end{array}$ & $\begin{array}{c}26.0 \pm \\
45.7\end{array}$ & $\begin{array}{c}791 \pm \\
1053\end{array}$ & $\begin{array}{l}6311 \pm \\
20922\end{array}$ \\
\hline All patients & $\begin{array}{c}4.3 \pm \\
13.0\end{array}$ & $\begin{array}{l}4905 \pm \\
14839\end{array}$ & $\begin{array}{l}0.3 \pm \\
2.3\end{array}$ & $\begin{array}{c}1150 \pm \\
9209\end{array}$ & $\begin{array}{l}4.6 \pm \\
13.6\end{array}$ & $\begin{array}{l}6055 \pm \\
18775\end{array}$ & $\begin{array}{c}12.1 \pm \\
22.7\end{array}$ & $\begin{array}{c}292 \pm \\
664\end{array}$ & $\begin{array}{c}23.3 \pm \\
43.0\end{array}$ & $\begin{array}{c}728 \pm \\
1005\end{array}$ & $\begin{array}{l}6346 \pm \\
19152\end{array}$ \\
\hline $\begin{array}{l}\text { Note: ICU = intensiv } \\
{ }^{*} \text { Includes all outpati } \\
\text { †Anatomical Therap } \\
\text { †Per-diem costs wer } \\
\text { §Includes only costs } \\
\text { medications only for }\end{array}$ & $\begin{array}{l}\text { unit, NA } \\
\text { sits. } \\
\text { Chemical } \\
39 \text { for the } \\
\text { sspital adm } \\
\text { including }\end{array}$ & $\begin{array}{l}\text { ot applic } \\
\text { ssificatio } \\
\text { neral war } \\
\text { ions and } \\
\text { ividuals }\end{array}$ & $\begin{array}{l}\text { SD = stan } \\
\text { des for carc } \\
\text { dd } \$ 3976 \text { for } \\
\text { sician visits } \\
65 \text { years a }\end{array}$ & $\begin{array}{l}\text { dard deviat } \\
\text { diovascular } \\
r \text { the ICU. } \\
\text { s for rows th } \\
\text { ind older. }\end{array}$ & $\begin{array}{l}\text { edications: } \\
\text { tinclude ind }\end{array}$ & $\begin{array}{l}\text { 09AA, C09E } \\
\text { iduals unde }\end{array}$ & $\begin{array}{l}\text { CO9CA, } \\
55 \text { years }\end{array}$ & $\begin{array}{l}\text { 9D, C02 } \\
\text { age and }\end{array}$ & $\begin{array}{l}\text { 07, C08, C01DA } \\
\text { Iditionally includ }\end{array}$ & $\begin{array}{l}\text { 10, C03, } \\
\text { cardiovas }\end{array}$ & SDA. \\
\hline
\end{tabular}

choice of ICD codes, top-down versus bottom-up costing (and, if the latter, the categories included) and perspective of the analysis (e.g., payer or societal). Given these caveats, investigators have shown that the annual cost-of-illness ranges from $\$ 868$ in South Korea (for 2014; in 2014 US dollars), ${ }^{12}$ through $\$ 20245^{3}$ (in 2012 US dollars) and \$20 $618^{34}$ (in 2008 US dollars) in the United States, to \$25 532 in Germany (for 2002 ; in 2014 US dollars). ${ }^{13}$

At least 2 findings related to the epidemiology of heart failure in Nova Scotia bear greater scrutiny. The prevalence, incidence and mortality in Nova Scotia were similar to those of other Canadian provinces (using the same algorithm, based on most responsible diagnosis, as was used here). ${ }^{23}$ The declining rates of hospital discharge for heart failure between 2009 and 2012 are consistent with declining incidence observed in Ontario, ${ }^{39}$ the United Kingdom ${ }^{40}$ and the US. ${ }^{41}$ Using the same algorithm to select patients as was used here, Tran and colleagues ${ }^{36}$ projected that hospital costs in Canada would increase from $\$ 482$ million (95\% confidence interval [CI] $\$ 464$ million to $\$ 500$ million) in 2013 to $\$ 722$ million (95\% CI \$650 million to \$801 million) in 2030 (costs standardized to 2014 Canadian dollars). If the incidence is declining, these estimates may shift downward.
In addition, survival in Nova Scotia may be lower than has been reported in the literature. ${ }^{42}$

The authors of The Need for Heart Failure Advocacy in Canada highlighted limited awareness of the "[heart failure] epidemic, the natural history of the disease, and the potential benefits of available therapies." They called for action from all stakeholders "outlining key targets for health care system redesign and policy initiatives that must be championed to affect [sic] meaningful change toward an optimal future for this disease state." ${ }^{7}$ As is the case elsewhere, ${ }^{9}$ hospital admissions accounted for the biggest component of costs in Nova Scotia. The finding of increased costs in the first year is also consistent with findings from other jurisdictions. Taken together, interventions and policies designed to reduce hospital admissions early in the course of the disease can serve as targets for evaluation, including improved medication adherence, ${ }^{43}$ pre-symptom identification, ${ }^{44}$ telemedicine,${ }^{45}$ improved care coordination, ${ }^{46}$ transfer to alternate levels of care ${ }^{47}$ clinical pathways ${ }^{48}$ or others ${ }^{49}$ designed to avoid acute exacerbations and lengthy hospital stays among patients with heart failure. Patients with more advanced disease may benefit from increased emphasis on palliative care services..$^{50}$ 


\begin{tabular}{|c|c|c|c|c|c|c|c|}
\hline \multirow[b]{2}{*}{ Age group, yr } & \multicolumn{7}{|c|}{ Year after diagnosis; incidence-based direct medical costs, $\$$, mean \pm SD } \\
\hline & 1 & 2 & 3 & 4 & 5 & 6 & 7 \\
\hline \multicolumn{8}{|l|}{ Men } \\
\hline $50-64^{*}$ & $\begin{array}{c}64640 \pm \\
152870\end{array}$ & $\begin{array}{c}17105 \pm \\
48073\end{array}$ & $\begin{array}{c}18221 \pm \\
57432\end{array}$ & $\begin{array}{c}16450 \pm \\
50349\end{array}$ & $\begin{array}{c}17792 \pm \\
81437\end{array}$ & $\begin{array}{c}13408 \pm \\
50829\end{array}$ & $\begin{array}{l}7762 \pm \\
26896\end{array}$ \\
\hline 65-80† & $\begin{array}{c}110001 \pm \\
206497\end{array}$ & $\begin{array}{c}23426 \pm \\
68003\end{array}$ & $\begin{array}{c}25262 \pm \\
59062\end{array}$ & $\begin{array}{c}18812 \pm \\
49022\end{array}$ & $\begin{array}{c}18645 \pm \\
54732\end{array}$ & $\begin{array}{c}15992 \pm \\
63582\end{array}$ & $\begin{array}{l}5216 \pm \\
10895\end{array}$ \\
\hline$>80 \dagger$ & $\begin{array}{c}164076 \pm \\
222214\end{array}$ & $\begin{array}{c}23066 \pm \\
49634\end{array}$ & $\begin{array}{c}28430 \pm \\
66698\end{array}$ & $\begin{array}{c}17269 \pm \\
46490\end{array}$ & $\begin{array}{l}9582 \pm \\
18202\end{array}$ & $\begin{array}{c}22842 \pm \\
49901\end{array}$ & $\begin{array}{c}20967 \pm \\
41126\end{array}$ \\
\hline All men* & $\begin{array}{c}120159 \pm \\
206602\end{array}$ & $\begin{array}{c}21184 \pm \\
58712\end{array}$ & $\begin{array}{c}23535 \pm \\
60563\end{array}$ & $\begin{array}{c}17353 \pm \\
48895\end{array}$ & $\begin{array}{c}16334 \pm \\
61209\end{array}$ & $\begin{array}{c}15860 \pm \\
56946\end{array}$ & $\begin{array}{l}9249 \pm \\
26440\end{array}$ \\
\hline \multicolumn{8}{|l|}{ Women } \\
\hline $50-64^{*}$ & $\begin{array}{l}93240 \pm \\
207830\end{array}$ & $\begin{array}{c}26074 \pm \\
90889\end{array}$ & $\begin{array}{c}13837 \pm \\
27050\end{array}$ & $\begin{array}{c}23486 \pm \\
58704\end{array}$ & $\begin{array}{c}12135 \pm \\
36964\end{array}$ & $\begin{array}{c}16952 \pm \\
41600\end{array}$ & $\begin{array}{c}1519 \pm \\
3819\end{array}$ \\
\hline $65-80 \dagger$ & $\begin{array}{c}107055 \pm \\
197685\end{array}$ & $\begin{array}{c}20997 \pm \\
48852\end{array}$ & $\begin{array}{c}20007 \pm \\
49984\end{array}$ & $\begin{array}{c}18421 \pm \\
46767\end{array}$ & $\begin{array}{c}16693 \pm \\
53260\end{array}$ & $\begin{array}{c}13723 \pm \\
36519\end{array}$ & $\begin{array}{c}14811 \pm \\
42874\end{array}$ \\
\hline$>80 \dagger$ & $\begin{array}{c}143821 \pm \\
185502\end{array}$ & $\begin{array}{c}22553 \pm \\
50256\end{array}$ & $\begin{array}{c}19187 \pm \\
49829\end{array}$ & $\begin{array}{c}15155 \pm \\
40477\end{array}$ & $\begin{array}{c}10015 \pm \\
37370\end{array}$ & $\begin{array}{c}11077 \pm \\
30187\end{array}$ & $\begin{array}{c}13083 \pm \\
38192\end{array}$ \\
\hline All women* & $\begin{array}{c}124606 \pm \\
193472\end{array}$ & $\begin{array}{c}21629 \pm \\
56439\end{array}$ & $\begin{array}{c}18177 \pm \\
47373\end{array}$ & $\begin{array}{c}17405 \pm \\
46600\end{array}$ & $\begin{array}{c}13043 \pm \\
45626\end{array}$ & $\begin{array}{c}13040 \pm \\
35584\end{array}$ & $\begin{array}{c}11474 \pm \\
37614\end{array}$ \\
\hline All patients* & $\begin{array}{c}122304 \pm \\
200358\end{array}$ & $\begin{array}{c}21396 \pm \\
57627\end{array}$ & $\begin{array}{c}21019 \pm \\
54818\end{array}$ & $\begin{array}{c}17377 \pm \\
47823\end{array}$ & $\begin{array}{c}14812 \pm \\
54556\end{array}$ & $\begin{array}{c}14575 \pm \\
48377\end{array}$ & $\begin{array}{c}10289 \pm \\
32093\end{array}$ \\
\hline $\begin{array}{l}\text { Note: } \mathrm{SD}=\text { stanc } \\
\text { *Includes costs } \\
\text { †Includes costs }\end{array}$ & $\begin{array}{l}\text { lation. } \\
\text { al admiss } \\
\text { al admiss }\end{array}$ & hysician & $\%$ & 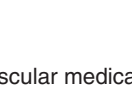 & & & \\
\hline
\end{tabular}

\begin{tabular}{|c|c|c|c|c|}
\hline \multirow[b]{2}{*}{ Age group, yr } & \multicolumn{2}{|c|}{ 1-365 d before death } & \multicolumn{2}{|c|}{$366-730 \mathrm{~d}$ before death } \\
\hline & $n$ & Cost, $\$$, mean \pm SD & $n$ & Cost, $\$$, mean \pm SD \\
\hline \multicolumn{5}{|l|}{ Men } \\
\hline $50-64^{*}$ & $<5$ & $26681 \pm 20056$ & $<5$ & $7409 \pm 14263$ \\
\hline 65-80† & 36 & $62623 \pm 123491$ & 36 & $9185 \pm 22632$ \\
\hline$>80 \dagger$ & 55 & $40921 \pm 47527$ & 54 & $6071 \pm 21865$ \\
\hline All men* & 95 & $48280 \pm 84321$ & 94 & $7110 \pm 21655$ \\
\hline \multicolumn{5}{|l|}{ Women } \\
\hline $50-64^{*}$ & 0 & NA & 0 & NA \\
\hline 65-80† & 17 & $47427 \pm 49952$ & 17 & $12530 \pm 43522$ \\
\hline$>80 \dagger$ & 62 & $35512 \pm 47428$ & 62 & $9634 \pm 26107$ \\
\hline All women* & 79 & $37819 \pm 47859$ & 79 & $10080 \pm 30334$ \\
\hline All patients* & 174 & $43531 \pm 70165$ & 173 & $8466 \pm 25943$ \\
\hline \multicolumn{5}{|c|}{$\begin{array}{l}\text { Note: } \mathrm{NA}=\text { not available, } \mathrm{SD}=\text { standard deviation. } \\
{ }^{*} \text { Includes costs of hospital admission and physician visits only. } \\
\text { †Includes costs of hospital admission, physician visits and outpatient cardiovascular medications. }\end{array}$} \\
\hline
\end{tabular}

\section{Limitations}

This study had some important limitations. In particular, follow-up commenced after each patient's first hospital admission, which meant that costs attributable to heart failure before this event were excluded and thus the actual costs of illness may have been underestimated. In this regard, one key 
piece of information typically absent from administrative health data is the severity of illness, which for heart failure is often measured using the New York Heart Association (NYHA) 4-level categorization. ${ }^{51}$ The first hospital admission for heart failure corresponds roughly to NYHA class III, when disease severity increases and patients become more susceptible to breathlessness requiring admission. In Poland, costs for patients with NYHA class I or II heart failure were between two-thirds and three-quarters of the costs for those with NYHA class III heart failure. ${ }^{52}$ Given the potentially larger number of individuals with less severe disease, the total costs could be substantial.

One advantage of the algorithm used in this study was its correspondence with that used by other Canadian investigators. ${ }^{11,23}$ However, the exclusion of costs for patients who died during the index admission would lead to underestimation of prevalence- and incidence-based costs.

One challenge with bottom-up costing studies is external validity. ${ }^{14}$ By using disaggregated values for length of stay and per-diem costs, future investigators can compare the values they observe with those reported here for Nova Scotia. However, given the similarity among Canadian provinces and territories in terms of organization of care, use of common national clinical practice guidelines, similar financing mechanisms and availability of administrative health data, there are fewer concerns that results will not be applicable to other Canadian jurisdictions.

We did not include any information on emergency department or other outpatient clinic costs or the costs of home services, such as oxygen, cardiac rehabilitation or palliative care, because the database where these resources are curated (the National Ambulatory Care Reporting System) is incomplete for Nova Scotia.

Because the perspective of this study was that of a provincial health payer, we excluded the costs for informal caregivers and lost productivity. One study showed these costs to be greater than the direct medical costs of heart failure. ${ }^{53} \mathrm{~A}$ similar phenomenon may exist in Nova Scotia, whereby a deterioration of health care facilities may increase the burden on home care. ${ }^{54}$

Given the complexity of costing medications for heart failure, ${ }^{40}$ we simplified the attribution of costs by including Anatomical Therapeutic Chemical codes for cardiovascular medications only. Similarly, for physician visits, we attributed to heart failure all billings from family physicians, cardiologists, general internists and cardiac surgeons. Although both of these assumptions led to misclassification, the direction of their combined effect on the direct medical costs of illness is unclear.

The costs of outpatient medications were assumed to be the same for patients aged 50 to 64 years as for older patients. In addition, the costs of medications administered in hospital were not isolated but rather were included in the in-hospital per diems.

\section{Conclusion}

Direct medical costs of treating patients with heart failure in Nova Scotia displayed a reverse J shape, with highest costs in the first year, a decline over subsequent years and an increase during the final year of life. Strategies designed to improve the quality of care immediately after diagnosis and at more severe stages of disease may reduce hospital episodes and costs.

\section{References}

1. Liao L, Allen LA, Whellan DJ. Economic burden of heart failure in the elderly. Pharmacoeconomics 2008;26:447-62.

2. Bundkirchen A, Schwinger RHG. Epidemiology and economic burden of chronic heart failure. Eur Heart 7 Suppl 2004;6(Suppl D):D57-60.

3. Voigt J, John MS, Taylor A, et al. A reevaluation of the costs of heart failure and its implications for allocation of health resources in the United States. Clin Cardiol 2014;37:312-21.

4. Hospital stays in Canada. Ottawa: Canadian Institute for Health Information; 2020. Available: https://www.cihi.ca/en/hospital-stays-in-canada (accessed 2021 Apr. 5).

5. All-cause readmission to acute care and return to the emergency department. Ottawa: Canadian Institute for Health Information; 2012.

6. Which bealth conditions were the most expensive in 2016-2017? Ottawa: Canadian Institute for Health Information. Available: https://www.cihi.ca/en/which -health-conditions-are-the-most-expensive (accessed 2021 Apr. 5)

7. Virani SA, Bains M, Code J, et al.; Board and Membership of the Canadian Heart Failure Society. The need for heart failure advocacy in Canada. Can 7 Cardiol 2017;33:1450-4.

8. 2016 report on the health of Canadians: The burden of heart failure. Ottawa: Heart \& Stroke Foundation; 2017.

9. Lesyuk W, Kriza C, Kolominsky-Rabas P. Cost-of-illness studies in heart failure: a systematic review 2004-2016. BMC Cardiovasc Disord 2018;18:74.

10. Shafie AA, Tan YP, Ng CH. Systematic review of economic burden of heart failure. Heart Fail Rev 2018;23:131-45.

11. Wijeysundera HC, Austin PC, Wang X, et al. The effect of multidisciplinary heart failure clinic characteristics on 1-year postdischarge health care costs: a population-based study. Med Care 2014;52:272-9.

12. Lee H, Oh SH, Cho H, et al. Prevalence and socio-economic burden of heart failure in an aging society of South Korea. BMC Cardiovasc Disord 2016;16:215.

13. Zugck C, Müller A, Helms TM, et al. Health economic impact of heart failure: an analysis of the nationwide German database [article in German]. Dtsch Med Wochenschr 2010;135:633-8.

14. Singh GK, Davidson PM, Macdonald PS, et al. The use of hospital-based services by heart failure patients in the last year of life: a discussion paper. Heart Fail Rev 2019;24:199-207.

15. Russo MJ, Gelijns AC, Stevenson LW, et al.; REMATCH Investigators. The cost of medical management in advanced heart failure during the final two years of life. 7 Card Fail 2008; 14:651-8.

16. Kaul P, McAlister FA, Ezekowitz JA, et al. Resource use in the last 6 months of life among patients with heart failure in Canada. Arch Intern Med 2011;171:211-7.

17. Rice DP. Cost-of-illness studies: Fact or fiction? Lancet 1994;344:1519-20.

18. Ament A, Evers S. Cost of illness studies in health care: a comparison of two cases. Health Policy 1993;26:29-42.

19. Kennedy S. De-identification and linkage policy. Halifax: Dalhousie University, Department of Community Health and Epidemiology, Health Data Nova Scotia; 2017. Available: https://cdn.dal.ca/content/dam/dalhousie/pdf/faculty/ medicine/departments/department-sites/community-health/research/hdns/ 5_De-identification \% 20and\%20Linkage\%20Policy_05-04-17.pdf (accessed 2021 Feb. 10)

20. Hinds A, Lix LM, Smith M, et al. Quality of administrative health databases in Canada: a scoping review. Can 7 Public Health 2016;107:e56-61.

21. Rosamond WD, Chang PP, Baggett C, et al. Classification of heart failure in the atherosclerosis risk in communities (ARIC) study: a comparison of diagnostic criteria. Circ Heart Fail 2012;5:152-9.

22. Quach S, Blais C, Quan H. Administrative data have high variation in validity for recording heart failure. Can 7 Cardiol 2010;26:306-12.

23. Blais C, Dai S, Waters C, et al. Assessing the burden of hospitalized and community-care heart failure in Canada. Can 7 Cardiol 2014;30:352-8.

24. Andersson C, Vasan RS. Epidemiology of cardiovascular disease in young individuals. Nat Rev Cardiol 2018;15:230-40.

25. Table: 17-10-0005-01 annual demographic estimates: Canada, provinces and territories, population estimates on July 1st, by age and sex. Ottawa: Statistics Canada. Available: https://www150.statcan.gc.ca/t1/tbl1/en/tv.action?pid $=1710000501$ (accessed 2021 Aug. 10).

26. Larg A, Moss JR. Cost-of-illness studies: a guide to critical evaluation. Pharmacoeconomics 2011;29:653-71.

27. DAD resource intensity weights and expected length of stay (ELOS) for $C M G+2020$. Ottawa: Canadian Institute for Health Information; 2020. Available: https:// secure.cihi.ca/estore/productSeries.htm?pc=PCC90 (accessed $2021 \mathrm{Apr}$. 5).

28. Cost of a standard hospital stay. Ottawa: Canadian Institute for Health Information. Available: https://yourhealthsystem.cihi.ca/hsp/inbrief?lang=en\#!/ indicators/015/cost-of-a-standard-hospital-stay/;mapC1;mapLevel2;/ (accessed 2021 Aug. 12). 
29. Table: 18-10-0005-01: Consumer Price Index, annual average, not seasonally adjusted. Available: https://www150.statcan.gc.ca/t1/tbl1/en/tv. action?pid=1810000501 (accessed 2021 Feb. 10).

30. Physician's manual 2014. Nova Scotia Medical Services Insurance, Medavie Blue Cross. Available: www.medavie.bluecross.ca/static/MSI/PhysicianManual.pdf (accessed 2021 Feb. 10).

31. Nova Scotia Pharmacare: formulary. Halifax: Government of Nova Scotia. Available: https://novascotia.ca/dhw/pharmacare/formulary.asp (accessed 2021 Feb. 10).

32. CADTH methods and guidelines: guidelines for the economic evaluation of health technologies: Canada. 4th ed. Ottawa: Canadian Agencies for Drugs and Technology in Health (CADTH); 2017.

33. Wijeysundera HC, Wang X, Tomlinson G, et al. Techniques for estimating health care costs with censored data: an overview for the health services researcher. Clinicoecon Outcomes Res 2012;4:145-55.

34. Dunlay SM, Shah ND, Shi Q, et al. Lifetime costs of medical care after heart failure diagnosis. Circ Cardiovasc Qual Outcomes 2011;4:68-75.

35. Hawkins NM, Virani S, Ceconi C. Heart failure and chronic obstructive pulmonary disease: the challenges facing physicians and health services. Eur Heart 7 2013;34:2795-803

36. Tran DT, Ohinmaa A, Thanh NX, et al. The current and future financial burden of hospital admissions for heart failure in Canada: a cost analysis. CMA7 Open 2016;4:E365-70

37. Samsky MD, Ambrosy AP, Youngson E, et al. Trends in readmissions and length of stay for patients hospitalized with heart failure in Canada and the United States. FAMA Cardiol 2019;4:444-53.

38. Mauskopf J. Prevalence-based economic evaluation. Value Health 1998; 1:251-9.

39. Yeung DF, Boom NK, Guo H, et al. Trends in the incidence and outcomes of heart failure in Ontario, Canada: 1997 to 2007. CMA7 2012;184:E765-73.

40. Conrad N, Judge A, Tran J, et al. Temporal trends and patterns in heart failure incidence: a population-based study of 4 million individuals. Lancet 2018; 391:572-80

41. Gerber Y, Weston SA, Redfield MM, et al. A contemporary appraisal of the heart failure epidemic in Olmsted County, Minnesota, 2000 to 2010. 7 AMA Intern Med 2015;175:996-1004.

42. Pocock SJ, Ariti CA, McMurray JJV, et al. Predicting survival in heart failure: a risk score based on 39372 patients from 30 studies. Eur Heart 7 2013;34:1404-13.

43. Wu JR, Moser DK, Chung ML, et al. Predictors of medication adherence using a multidimensional adherence model in patients with heart failure. 7 Card Fail 2008;14:603-14.

44. Abraham WT, Adamson PB, Bourge RC, et al. Wireless pulmonary artery haemodynamic monitoring in chronic heart failure: a randomised controlled trial. Lancet 2011;377:658-66.

45. Voigt J, Mosier M. Remote care costs for congestive heart failure: a systematic review and meta-analysis of randomized controlled trials in the United States comparing remote versus more intensive care settings. Congest Heart Fail 2013;19:192-9.

46. Bradley EH, Curry L, Horwitz LI, et al. Hospital strategies associated with 30-day readmission rates for patients with heart failure. Circ Cardiovasc Qual Outcomes 2013;6:444-50.

47. Allen LA, Hernandez AF, Peterson ED, et al. Discharge to a skilled nursing facility and subsequent clinical outcomes among older patients hospitalized for heart failure. Circ Heart Fail 2011;4:293-300.

48. Hollenberg SM, Warner Stevenson L, Ahmad T, et al. 2019 ACC expert consensus decision pathway on risk assessment, management, and clinical trajectory of patients hospitalized with heart failure: a report of the American College of Cardiology Solution Set Oversight Committee [published erratum in $7 \mathrm{Am}$ Coll Cardiol 2020;75:132]. 7 Am Coll Cardiol 2019;74:1966-2011.

49. Wright SP, Verouhis D, Gamble G, et al. Factors influencing the length of hospital stay of patients with heart failure. Eur 7 Heart Fail 2003;5:201-9.

50. Kavalieratos D, Mitchell EM, Carey TS, et al. "Not the 'grim reaper service": an assessment of provider knowledge, attitudes, and perceptions regarding palliative care referral barriers in heart failure. $7 \mathrm{Am}$ Heart Assoc 2014;3:e000544.

51. New York Heart Association, Criteria Committee. Nomenclature and criteria for diagnosis of diseases of the heart and great vessels. 9th ed. Boston: Little, Brown and Company; 1994:253-6.

52. Czech M, Opolski G, Zdrojewski T, et al. The costs of heart failure in Poland from the public payer's perspective. Polish programme assessing diagnostic procedures, treatment and costs in patients with heart failure in randomly selected outpatient clinics and hospitals at different levels of care: POLKARD. Kardiol Pol 2013;71:224-32.

53. Delgado JF, Oliva J, Llano M, et al. Health care and nonhealth care costs in the treatment of patients with symptomatic chronic heart failure in Spain. Rev Esp Cardiol (Engl Ed) 2014;67:643-50.

54. Fierlbeck K. Nova Scotia: a health system profile. Toronto: University of Toronto Press; 2018.

Affiliations: Department of Community Health and Epidemiology (Levy), Faculty of Medicine, Dalhousie University, Halifax, NS; Broadstreet Health Economics \& Outcomes Research (Johnston, Rogula) and Division of Cardiology (Ignaszewski), Department of Medicine, Faculty of Medicine, University of British Columbia, Vancouver, BC; Novartis Pharmaceuticals Canada Inc. (Daoust, Fortier), Dorval, Que.; Toronto Rehabilitation Institute (Oh), Toronto, Ont.

Contributors: Adrian Levy, Karissa Johnston, Alexia Daoust, Andrew Ignaszewski, Jonathan Fortier and Paul Oh contributed to the conception and design of the study. Adrian Levy, Karissa Johnston and Basia Rogula acquired the data; Karissa Johnston and Basia Rogula analyzed the data; and Adrian Levy, Karissa Johnston and Basia Rogula interpreted the data. All of the authors contributed to drafting and revising the manuscript, gave final approval of the version to be published and agreed to be accountable for all aspects of the work.

Funding: Funding for this study was provided by Novartis Pharmaceuticals Canada Inc. to Broadstreet Health Economics \& Outcomes Research. As per the statement of competing interests, several of the authors were employed by, or served as consultants to, Novartis Canada, and one as a consultant to Broadstreet Health Economics \& Outcomes research. Their contributions and perspectives are reflected in the current manuscript in the same way as those of all other authors. The contract with Novartis Pharmaceuticals Canada did not allow the sponsor to withhold the decision to publish.

Content licence: This is an Open Access article distributed in accordance with the terms of the Creative Commons Attribution (CC BY-NC-ND 4.0) licence, which permits use, distribution and reproduction in any medium, provided that the original publication is properly cited, the use is noncommercial (i.e., research or educational use), and no modifications or adaptations are made. See: https://creativecommons.org/licenses/ by-nc-nd/4.0/

Data sharing: The data used in this study were obtained from Health Data Nova Scotia, and the authors no longer have access to these data. As such, the data are not immediately available for sharing, although the analysis could be replicated.

Supplemental information: For reviewer comments and the original submission of this manuscript, please see www.cmajopen.ca/content/9/3/ E826/suppl/DC1 